\title{
ELEMENTOS VERBAIS E NÃO VERBAIS DA COMUNICAÇÃO NO SANTUÁRIO NACIONAL DA UMBANDA
}

\author{
Verbal and non-verbal elements of communication in the Umbanda National \\ Sanctuary
}
Elementos verbales y no verbales de la comunicación en el Santuario Nacional de Umbanda

Regina Rossetti

Professora do Programa de Pós-Graduação em Comunicação da

Universidade Municipal de São Caetano do Sul regina.rossetti@prof.uscs.edu.br

Carlos Henrique Oliveira Dias Mestre pelo Programa de Pós-Graduação em Comunicação da Universidade Municipal de São Caetano do Sul cdias_cdias@yahoo.com.br

\section{Resumo}

O presente artigo pretende identificar os elementos verbais e não verbais da comunicação presentes no ambiente religioso do Santuário Nacional da Umbanda, localizado em Santo André (SP). Através da historicidade da Umbanda e de pesquisa in loco, analisamos os pontos cantados, os pontos riscados e as imagens presentes no Santuário como forma de expressão da comunicação, sendo ela verbal ou não verbal.

Palavras-chave: Comunicação religiosa. Inovação. Umbanda.

\begin{abstract}
The present article intends to identify the verbal and non-verbal elements of the communication present in the religious environment of the Umbanda National Sanctuary, located in Santo André (SP). Through the historicity of Umbanda and in loco research, we analyze the sung points, the crossed out points and the images present in the Sanctuary as a form of communication expression, whether verbal or non-verbal.
\end{abstract}

Key-words: Communication. Innovation. Umbanda. 


\section{Resumen}

el presente artículo tiene como objetivo identificar los elementos verbales y no verbales de la comunicación en el ambiente religioso del Santuario Nacional de Umbanda, ubicada en Santo André (SP). A través de la historicidad de la Umbanda y del investigación in loco, analizamos los puntos cantos, los puntos rayados y las imágenes presentes en el Santuario como forma de expresión de la comunicación, siendo verbal o no verbal.

Palabras-clave: Comunicación. Innovación. Umbanda.

\section{INTRODUÇÃO}

Um dos maiores símbolos da evolução humana é o processo pelo qual o homem se comunica. A necessidade do homem de se comunicar fez com que este criasse formas de interação por meio de símbolos, gestos, emissão de sons e a escrita. A proposta desse artigo é abordar os elementos da comunicação verbal e não verbal no espaço religioso do Santuário Nacional da Umbanda, localizado em Santo André (SP),. Os elementos da comunicação verbal podem ser encontrados no formato midiático e na tradição oral. A comunicação midiática dá-se pelo site do Santuário e pelas mídias sociais. A comunicação por meio da oralidade é partilhada pelos membros que participam dos rituais religiosos e materializa-se por meio das narrativas religiosas da tradição umbandista. Os elementos da comunicação não verbal podem ser investigados dentro desse campo religioso apoiados nas premissas da Umbanda como forma de interação social, na visualidade das imagens religiosas e dos símbolos e na expressão corporal e gestual nos rituais. A metodologia utilizada envolveu revisão bibliográfica e pesquisa de campo.

Por tratar-se de um ambiente religioso, obviamente é carregado de simbologias e significados relacionados única e exclusivamente à Umbanda. A história da Umbanda permeia vários reveses, já que não existem documentos oficiais que registrem o "nascimento" ou "fundação" da religião. Sabe-se que a Umbanda surgiu de insatisfação espiritual de entidades espíritas que não trabalhavam nas linhagens do espiritismo kardecista nem baseadas no candomblé puramente africano (ORTIZ, 1999).

Buscamos identificar as linguagens e simbolismos como forma de comunicação na Umbanda e, para isso, trazemos os pontos cantados nos terreiros como elemento verbal e sua significância dentro de culto ritualístico umbandista. Para ilustrarmos o sentido da comunicação não verbal na Umbanda, os pontos riscados foram tratados de forma singular como elemento comunicacional entre entidade e o divino, assim como alguns tipos 
diferenciados da grafia desses pontos. Para finalizarmos o levantamento trazemos os elementos verbais e não verbais da comunicação encontrados e categorizados no Santuário Nacional da Umbanda, bem como os resultados obtidos na investigação.

\section{COMUNICAÇÃO NA UMBANDA: LINGUAGENS E SIMBOLISMOS}

Um dos maiores indicadores da evolução humana é o processo pelo qual o homem se comunica. Desde os tempos mais remotos da história, o surgimento dos agrupamentos humanos aconteceu pela necessidade de o homem se relacionar, já que ele é um ser social. Também remonta de tempos pré-históricos a relação do homem com o sagrado, com o intangível. Desde os primeiros agrupamentos humanos a relação entre o homem e o divino se faz presente nos mais variados momentos: colheitas, ritos na transição da infância/puberdade à vida adulta, para vencer pelejas. Enfim, o ser humano, em sua maioria, é movido por algum tipo de fé, crença e mitos, e até mesmo os que não creem acabam dispensando certa 'fé' ao inexistente.

Obviamente o conceito de religião não cabe somente ao fato de acreditar ou não em algo, porém muitas vezes o vínculo entre o indivíduo e a religião passa a ser somente para se dar um sentido de vida, expressando sentimentos que por vezes são relacionados e condicionados à religião. Para tanto, podemos nos apoiar no que a literatura acadêmica nos oferece:

[...] a religiosidade não significa necessariamente a opção por uma crença religiosa, mas pode ser uma das possíveis maneiras de o homem encontrar sentido para a vida. O ser humano é o único que pode conscientemente escolher o direcionamento de suas ações, tornando claras as intenções de sua essência e, através de suas atitudes, demonstrar o valor de suas palavras, o poder de seus pensamentos e o calor de seus sentimentos em tudo o que realiza. As atitudes ocupam um espaço considerável na vida, influenciando inúmeras decisões e comportamentos. E, à medida que as pessoas se relacionam com o meio social, formam atitudes em relação a esse ambiente (AQUINO et al, 2009, p. 229-233).

Não obstante, podemos encontrar as concepções e experiências acerca da religião nas mais variadas áreas do conhecimento: na Antropologia, na História, na Sociologia, na Filosofia, nas Ciências Médicas - está sempre relacionando o divino, a crença e a cura. Logo, por que não buscarmos a relação desta com a comunicação?

Podemos entender a comunicação como uma relação social, uma troca de informações, signos e mensagens que nos acompanham desde a infância até a vida adulta. Portanto, 
ou aquela pessoa; falar num certo tom de voz e assim por diante. Isto quer dizer que as situações de comunicação são muitas e diversificadas (RECTOR; TRINTA, 2005, p. 8).

Sabemos que a comunicação consiste num sistema complexo de interpretações e que podemos encontrá-la nas mais variadas formas e conceitos. É um processo de interação que envolve mensagens, ideias, contextos, que de certa maneira pode induzir comportamentos e instigar os indivíduos. Assim, não seria diferente ao tratarmos a comunicação no campo religioso, seja esse campo em qualquer dogma, doutrina ou segmento, não sendo diferente se focarmos na Umbanda.

O universo umbandista é cercado de simbologias e linguagens e, sem dúvidas, o processo comunicacional está presente nos seus ritos e cultos. Como primeiro aspecto comunicacional da Umbanda é o símbolo que a representa, a Estrela de Davi. A Estrela de Davi representa as Sete Linhas da Umbanda ${ }^{1}$, e que são representados em sentido anti-horário: Iemanjá, Oxóssi, Ogum, Xangô, Oxum e Iansã, tendo ao centro Oxalá. Para cada linha de orixá existe uma série de entidades que corroboram nos trabalhos espirituais. É válido ressaltar que cada orixá representado na Estrela de Davi também carrega a força da natureza ou atividade que simboliza.

Sendo assim, já é possível traçarmos relação entre o símbolo representativo com o que expressa a linguagem enquanto seu significado. Partindo da ideia de que o símbolo tem a incumbência de transmitir algo, podemos assegurar que:

\begin{abstract}
Pode-se afirmar que o símbolo tem a função de comunicar, porque essa é sua intencionalidade, dar analogicamente outro sentido, mais aberto, universal, transcendental. Outra característica é sua capacidade de múltiplos significados, é aberto e possibilita a manifestação do maravilhoso, do mistério na realidade história. Uma experiência religiosa carrega uma significação transcendental, ainda que seja percebido de forma fragmentada seu conteúdo necessita ser explicitado por mediações abertas, então a importância da compreensão do simbólico nos espaços religiosos e na formação de grupos de redes (GALAGARRA, 2014, p. 1283).
\end{abstract}

Assim como o símbolo transmite informações ao receptor em qualquer esfera, não seria diferente na Umbanda enquanto religião. Entendemos a linguagem simbólica como forma de expressão e podemos ser mais perspicazes se a entrelaçarmos com uma forma ritualística, religiosa.

Podemos considerar a linguagem ritualística relevante, porque as ações do homem enquanto ser social são transmitidas por rituais e essa linguagem intenciona agregar o ser

\footnotetext{
${ }^{1}$ Dentro da Umbanda existe uma organização em que espíritos e entidades trabalham por um bem comum seguindo um orixá, que atua como uma espécie de chefe. Cada linha tem uma vibração e existe para um propósito, que sustenta e influencia a vida de todos os seres.
} 
humano, enquanto a linguagem ritual religiosa pretende ir além, pois interage com o que é transcendental, metafísico (BAUMANN, 2010).

Para compreender esse sentido que a religião ritualística exerce sobre a sociedade, mais uma vez podemos utilizar as concepções de cultura para elucidar essa relação entre homem-divino-fé. Em primeiro plano podemos usar os saberes antropológicos da cultura, que é revestida de simbologias, signos e nos mostra a capacidade humana de interagir com esses significados para que se alcance o que fora almejado (SETTON, 2008).

Dessa maneira, nos torna um pouco mais visível de que a religião também é produtora de cultura e que funciona como agente socializador seja em sua forma de exteriorizar ou interiorizar a fé, ou mesmo em seu processo de linguagem e comunicação:

Em síntese, conceber as religiões como matrizes de cultura é considera-las enquanto sistemas de símbolos, com linguagem própria, distintas das demais matrizes de cultura que compõem o universo socializador do indivíduo contemporâneo (SETTON, 2008, p. 16)

Obviamente que a Umbanda não se resume somente à Estrela de Davi. Esse é somente um dos elementos trabalhados na religião, pois a gama de linguagens e simbologias é grande. Porém, ainda há pouca exploração quando tratamos de símbolos na Umbanda, conforme nos aponta a literatura:

Se, por um lado, tem-se avaliado o movimento umbandista, sua história, seu surgimento na sociedade brasileira, por outro lado pouca atenção tem sido dedicada aos seus símbolos rituais em interação com a história de vida das pessoas, bem como seus grupos ou comunidades (PAGLIUSO; BAIRRÃO, 2010, p. 196).

Por si só, a Umbanda já nasceu como símbolo, pois rompe com a caracterização de religião africana, propondo ser uma religião universal (não somente para negros) e como representação simbólica de um país tomado pela mestiçagem como é o Brasil (PRANDI, 2003). São muitos os rituais presentes nos cultos umbandistas e podemos dizer que cada "parte" desses ritos tem seu significado. Além da representação pela Estrela de Davi, há os rituais de abertura de gira ${ }^{2}$ o ato de bater a cabeça no Congá $a^{3}$, a defumação do ambiente, o ritual do pó de pemba ${ }^{4}$, das águas, das preces de agradecimento para finalmente dar início ao chamamento das entidades que respeitam uma hierarquia, embora haja Umbandas que podem dedicar cada dia de trabalho a uma entidade específica (às segundas, preto-velho; às quartas, caboclos etc.). Ponto bastante relevante na construção das linguagens e símbolos da Umbanda

\footnotetext{
${ }^{2}$ É considerada gira a roda de adeptos que se reúnem para iniciar os trabalhos nos templos de Umbanda.

${ }^{3}$ Cf. "Dicionário da Umbanda", altar.

${ }^{4}$ Cf. "Dicionário da Umbanda", Espécie de giz em forma cônico-arredondada, colorida em diversas cores.
} 
está também a expressão corporal muito utilizada nas danças, principalmente quando da possessão ${ }^{5}$ das entidades.

Assim como cada orixá representa uma força da natureza, conforme vimos, no caso das entidades, em cada uma delas há um ato gestual comunicacional. Em termos gerais, a Umbanda trabalha com entidades espirituais como preto-velho, boiadeiro, marinheiro, caboclo, baiano, São Cosme e São Damião, exus e pombogiras.

Não pretendemos aqui traçar ponto a ponto dos rituais umbandistas, mas sim oferecer uma noção da relevância do sentido das linguagens e simbolismos praticados na religião. Estamos tratando de simbologias de uma gira cotidiana, pois ainda há outros eventos sacramentais na Umbanda que remetem a práticas ritualísticas litúrgicas, como batizados, casamentos e comemorações específicas, que são compostas de elementos verbais e não verbais da comunicação que veremos a seguir.

\section{COMUNICAÇÃO VERBAL: OS PONTOS CANTADOS DA UMBANDA}

Também remonta de tempos antigos a relação entre a religião e a música, o que podemos observar até os dias atuais, seja na Umbanda, no Catolicismo, nas religiões Protestantes, enfim, sempre há uma ligação entre o homem-fé-divino. Em algumas religiões são tidas como cânticos, hinos e, no caso da Umbanda especificamente, os pontos cantados.

Por meio dos pontos cantados é que se dá início, andamento e encerramento aos rituais litúrgicos em uma gira umbandista. Grosso modo, podemos entender os pontos cantados como orações e preces musicadas com a finalidade de buscar a conexão entre entidade/orixá com o médium, conforme pode-se observar:

É através da oração em forma de música que as entidades dão seus recados, contam suas histórias, explicam em que estão trabalhando, o como e o motivo de o fazerem. Há pontos - também chamados de "corimbas" - comuns, recorrentes em todos os rituais e encontrados em quase todos os terreiros, e há aqueles particulares, que são verdadeiros presentes das entidades para seus filhos (BARROS; GOMES, 2014, p. 59).

Para termos uma ideia mais concreta do exposto, analisaremos a letra de um ponto cantado que é comum a todos os terreiros e templos umbandistas, o Hino da Umbanda, composto em 1961 por José Manoel Alves e musicado por Dalmo de Andrade Reis ${ }^{6}$ :

Refletiu, a luz divina, com todo seu esplendor. É do reino de Oxalá, onde há paz e amor. Luz que refletiu na terra, luz que refletiu no ar. Luz que veio de Aruanda, para tudo iluminar. A Umbanda é paz e amor, é um mundo cheio de luz, é a força que nos

\footnotetext{
${ }^{5}$ Termo utilizado para denominar a incorporação por um espírito ou entidade.

${ }^{6}$ Disponível em <http://sagrada-umbanda.blogspot.com.br/2012/06/historia-do-hino-da-umbanda-e-sualetra.html $>$. Acessado em 4 jan. 2017.
} 
dá vida e a grandeza nos conduz. Avante, filhos de fé! Como a nossa lei não há. Levando ao mundo inteiro a bandeira de Oxalá (José Manoel Alves, 1961).

Em toda a sua letra, é nítida a representação do que vem a ser a Umbanda, ou seja, entra em consonância o que prega os dogmas da religião: caridade, amor e a intenção de se levar paz (representada pela bandeira de Oxalá) ao mundo todo.

Não obstante, ainda podemos relacionar o hibridismo religioso junto aos pontos cantados da Umbanda, uma vez que existe uma relevância histórica e social que está propensa à transgressão às práticas da religião através da hibridação entre os ritos africanos e indígenas, podendo ainda remeter ao Catolicismo ao citar entre suas estrofes santos católicos. É comum encontrarmos nos pontos cantados da Umbanda referências a São Benedito, Bom Jesus da Lapa, Nossa Senhora, entre outros santos, como se vê no ponto do ritual de defumação:

Nossa Senhora incensou seu bento filho. Incensou para cheirar. Incensa essa casa, para o mal sair e a felicidade entrar. Eu incenso eu vou incensando. Eu incenso eu vou incensando, a casa do meu Bom Jesus da Lapa, a casa do meu Bom Jesus da Lapa (domínio público).

Ou ainda o ponto de saudação e chamamento dos caboclos:

Olha o meu passarinho azulão, quando ele voa não pousa no chão. Como é linda a cabocla Jurema, peito de aço e bodoque na mão. Aê, Juremê! Aê, Juremá! Sua flecha caiu serena, Jurema, dentro desse Congá. Salve São Jorge Guerreiro, salve São Sebastião, salve o povo da Umbanda e eu peço a minha proteção (domínio público).

Com grande contribuição dos negros africanos que aqui aportaram podemos destacar a música, que até os dias atuais se faz presente, a partir da liturgia ritualística aos deuses ligados às forças da natureza, fazendo com que os afrodescendentes mantivessem suas tradições através da sonoridade e musicalidade, fazendo com que estas tenham forte significância na Umbanda.

\section{COMUNICAÇÃO NÃO VERBAL: OS PONTOS RISCADOS DA UMBANDA}

Ainda sobre a comunicação dentro dos rituais da Umbanda não podemos nos apegar somente no que tange à sua forma verbal de expressão, já que inúmeras são as maneiras de manifestação dentro de um mesmo culto.

Conforme mencionado anteriormente, os rituais umbandistas são sempre marcados pelas suas simbologias, misticismos e sincretismos, mas também na comunicação não verbal na relação entre consulente-entidade, chefe de terreiro-consulentes etc. Para elucidarmos essa questão, podemos nos apoiar na literatura de Santos, que condensa o significado da comunicação não verbal: 
[...] é, portanto, o ato comunicacional que se efetua entre pessoas por meio que não a palavra. Em um processo de comunicação interpessoal estão envolvidos diversos elementos que contribuem (e, em determinados casos até atrapalham) para a conversação: além da linguagem verbal usada na conversa, os interlocutores gesticulam, assumem posições e fazem movimentos corporais que têm significações (SANTOS, 2003, p. 31).

Podemos considerar ainda vários outros elementos na Umbanda que nos remetam à comunicação não verbal, como gestos, expressões corporais das danças, banhos e unções. Obviamente que cada um com seu significado e relevância dentro do ritual, porém vamos falar aqui da significância dos pontos riscados.

Segundo o "Dicionário da Umbanda", temos a afirmação de que os trabalhos umbandistas,

[...] provindos das velhas seitas, foram sempre iniciados com riscos, ou pontos riscados, com o significado de letras ou hieróglifos, de acordo com a Linha a que pertencesse a entidade que fosse praticar o trabalho de magia, necessário naquele momento. é a Pemba, na Umbanda, a força misteriosa da escrita astral de nossa seita, que tem o poder de fechar, trancar ou abrir os terreiros, de acordo com as exigências dos trabalhos que vão ser praticados. Não pode existir um terreiro e muito menos um trabalho de magia sem o testemunho dos pontos riscados, isto é, da Pemba (PINTO, 1971, p. 152).

Ou seja, a Umbanda acabou por herdar, de certa maneira, os símbolos pictóricos que também já eram utilizados nas seitas mais arcaicas. O autor ainda destaca a Pemba como instrumento primordial desse processo comunicacional, pois, ainda segundo Pinto, não há Umbanda sem a presença da Pemba.

Conforme pesquisa de campo $^{7}$ baseada na observação direta dos rituais umbandistas no Templo de Umbandomblé Mamãe Oxum, em Campinas (SP), no processo de iniciação dos filhos de fé da Umbanda, não é comum um médium rodante ${ }^{8}$ já começar incorporando e atendendo ao público. Existe todo um processo de firmação ${ }^{9}$ do médium e, em alguns terreiros, considera-se esse médium e entidade prontos para trabalhar mediante a execução do ponto riscado pela entidade. Esse processo de amadurecimento da entidade e do médium pode levar meses e por vezes anos. Segundo os preceitos da prática umbandista, o ponto riscado pela entidade é o "sinal verde" que esta tem para iniciar as curimbas ${ }^{10}$.

\footnotetext{
${ }^{7}$ Pesquisa de campo realizada entre novembro/2016 e janeiro/2017.

${ }^{8}$ Designação de adeptos da Umbanda que têm o dom da incorporação.

${ }^{9}$ Mesmo sentido de firmeza, ou seja, a entidade do médium estar pronta para trabalhar, dar passes, oferecer consulta à assistência.

${ }^{10}$ Sinônimo de trabalho.
} 
Foi observado que, seguindo a linha dos ensinamentos da Umbanda (e em muitas de suas vertentes), o que o indivíduo carrega desde seu nascimento são $\operatorname{carmas}^{11}$, que desencadeiam nesse plano atual, logo, carregam heranças de vidas passadas.

Na prática umbandista, ao trazer ícones e sinais riscados, reproduz-se o legado dos ancestrais, fazendo com que esses paradigmas esquecidos venham à tona, formando assim uma inconsciência coletiva (SOLERA, 2014).

É possível compreender que a função do ponto riscado é uma afirmação entre a entidade e o cósmico, pois é por meio dessa simbologia que ela (a entidade) apresenta seu nome, sua linha de trabalho, a qual ou a quais orixás é cativa ${ }^{12}$ e quais elementos da natureza carrega.

Nesse sentido simbólico, também é possível perceber os diferentes traçados e riscados em cada ponto, ou seja, cada entidade possui suas características de trabalho. Como exemplos, podemos citar as flechas sempre presentes nos pontos de caboclo, coqueiros em pontos de baiano, traçados que designam ondas em pontos de marinheiro, foices e fogo nos pontos de exu e assim por diante, respeitando sempre qual categoria pertence cada entidade, como nos aponta Solera:

[...] ao chegar o momento de traçar o ponto riscado, é remetido a uma nova estrutura. [...] É nesse momento que ele vai incorporar os atributos dos ancestrais, bem como dos elementos simbólicos que estão grafados naqueles sinais (SOLERA, 2014, p. 82).

Diante disso, a relevância e significância do ponto riscado nos são mais latentes se relacionarmos com a maturidade da entidade e a credibilidade que esta vem a passar ao chefe de terreiro ou pai de santo e, sobretudo, aos seus consulentes.

Na visão de Rivas Neto ${ }^{13}$, em sua obra "Umbanda: a Proto-Síntese Cósmica” (2002), o ponto riscado é muito mais do que simples desenhos no solo de um terreiro e deve haver o máximo de cuidado em sua feitura e interpretação.

Não se deve, de forma alguma, tentar reproduzir um ponto riscado, ou considerar parte dele em uma cópia, pois há sérios riscos de turbulências espirituais, colocando o médium, ou

\footnotetext{
${ }^{11}$ Do sânscrito karma, nas religiões espiritualistas é a consequência de vidas passadas, as quais dirigem a vida presente e organizam as futuras e, para melhorar a vida presente e as futuras, é indispensável que o indivíduo se desembarace e se liberte dos resíduos das vidas anteriores, limpando o seu karma e evitando olhar a humanidade de acordo com as suas necessidades pessoais, elevando seus olhos um pouco mais alto que a verticalidade humana.

${ }^{12}$ Nesse aspecto não se aplica o sentido vernáculo da palavra (escravo), mas sim designa para qual ou em nome de qual santo a entidade responde, trabalha.

${ }^{13}$ Rivas Neto é sacerdote umbandista, escritor e um dos fundadores da Universidade de Teologia Umbandista em São Paulo.
} 
seus consulentes, em possíveis perigos, já que riscar Pemba é algo sério e demanda conhecimentos profundos da Lei de Pemba (RIVAS NETO, 2002).

Ou seja, o ponto riscado não se limita somente a desenhos e grafologias, mas sim a uma arquitetura pictórica que define desde sua origem, passando por elementos da natureza, forças cósmicas e afins. Esses pontos cósmicos e cabalísticos se apresentam por meio de grafias com representações bidimensionais que se maculam e projetam com poderes mágicos, e é por meio da energia do cosmo espiritual e da intercessão do corpo material (médium) que os significados chegam até nós.

Assim como nenhuma entidade é igual a outra, os pontos riscados também divergem. Ou seja, o Caboclo Sete Folhas que trabalha em um terreiro nunca será o mesmo que trabalha em outro, embora tenham o mesmo nome. Logo, o ponto riscado,

\begin{abstract}
$\mathrm{Na}$ verdade é o selo, o cartão de visitas, a identificação, o brasão e bandeira da entidade. É uma espécie de campo de força onde o instrumento utilizado pela entidade em seu efetivo campo de trabalho é a Pemba. E esta maneja as forças de sorte a lhe conferir afinidade com a entidade, identificada a quem ela se subordina, bem como os seus domínios ao ser usado para riscar o ponto. (DEMÉTRIUS, 2016, p. 277).
\end{abstract}

Defronte a isso, é perceptível a questão da identidade personificada da entidade. Da mesma forma que temos nossas digitais como fonte quase que exclusiva de identificação, as entidades trazem seus pontos como forma expressiva de consubstanciar seu arcabouço e características espirituais. Os pontos riscados são signos transcritos e sediados ao mundo espiritual que definem poderes, atividades e identificam falanges. Os pontos riscados são mágicos e não podem ser considerados apenas rabiscos (DEMÉTRIUS, 2016).

No entendimento de Demétrius (2016, p. 277-278), não basta olhar para um ponto em algum livro e simplesmente copiá-lo, transcrevê-lo ou ainda riscá-lo de forma invertida, pois esse ato profana e perverte a magia do ponto. $\mathrm{O}$ autor ainda adverte que o uso indevido de um ponto riscado pode causar consequências irreparáveis que ele mesmo compara a um leigo manejando uma rede elétrica, ou seja, perigo eminente.

Não obstante, até o momento falamos de pontos riscados como maneira de identificação e individualização das entidades e nos é concreto que seja um elemento comunicacional dentro da Umbanda, porém há outros tipos de pontos riscados que são utilizados (não somente na Umbanda) para os mais diversos trabalhos espirituais.

Como dito anteriormente, não existe ponto riscado sem a utilização da Pemba, logo, a mais comum a ser usada é a branca, mas há ainda entidades que prefiram as de outras cores: 
Quanto ao uso da Pemba, o estudo, o sentido e o valor das cores, só utiliza Pemba preta aquele que foi autorizado para tal. Na umbanda, o mais usual é o trabalho com a branca, azul, verde e amarela e por vezes vermelha. Lembro mais uma vez que todo ponto é magia, com todo significado de sua grafia e ondas vibratórias (DEMÉTRIUS, 2016, p. 278).

\section{O SANTUÁRIO NACIONAL DA UMBANDA: AMBIENTE COMUNICACIONAL}

Conforme vimos anteriormente, os processos que envolvem a comunicação estão presentes em qualquer forma de expressão e em qualquer espaço ou setor social, inclusive no meio religioso. Isso não seria diferente no Santuário Nacional da Umbanda.

Não podemos aqui discorrer sobre o Santuário Nacional da Umbanda sem mencionar uma das figuras mais importantes e emblemáticas da Umbanda no Brasil, Ronaldo Linares. Assim como acontece com vários umbandistas, espíritas etc., a própria história de vida de Ronaldo envolve suas experiências e práticas espirituais acerca de uma necessidade.

Ronaldo nasceu em São Paulo, na década de 1930, e ainda durante sua juventude sofreu um grave acidente que lhe comprometeu a coluna. Nesse período, mesmo frequentando alguns centros espíritas, ainda carregava sequelas do acidente (TRINDADE, 2009).

Decidido a mudar de ares, transferiu-se para o Rio de Janeiro, sem ao menos conhecer ninguém que pudesse ampará-lo.

Seu primeiro contato espiritualista no Rio de Janeiro foi por meio de um médico que conheceu em uma consulta para tentar reverter suas sequelas do acidente que sofrera, pois utilizava muletas e sua locomoção era danosa. Doutor Nelson chegou à conclusão de que a medicina não seria capaz de ajudá-lo e resolveu indicar-lhe um pai de santo:

Foi apresentado a João Alves Torres Filho, o famoso Joãozinho da Goméia, o Rei do Candomblé, figura polêmica e que era muito procurado por artistas, políticos e outras celebridades. Passou a morar na sua Roça de Candomblé, onde foi raspado, cortado, catulado, feito no santo e consagrado Babalaô ${ }^{14}$ (TRINDADE, 2009, p. 214).

Ronaldo criou fortes laços com Joãozinho da Goméia e foi este que lhe ensinou a arte oracular dos búzios, entre tantos outros conhecimentos místicos que o fazem ser reconhecido até os dias atuais como um pai de santo de excelência.

Linares orgulha-se de ter tido a oportunidade de conhecer e conviver com Zélio de Moraes e muito mais ainda de ter ouvido deste, em 1972, em seu primeiro encontro, que seria o responsável pela divulgação de suas obras pelo Brasil todo. Há cerca de 40 anos, Ronaldo visitou um local em Santo André (SP) onde havia funcionado a antiga Pedreira Montanhão,

\footnotetext{
${ }^{14}$ Pai de santo em iorubá.
} 
localizada em meio a uma encosta de mata. Ao deparar-se com a imensa cratera que a antiga exploradora de brita havia feito, Linares sentiu que com dedicação e esforço poderia transformar o lugar num antigo sonho: um local onde se pudesse cultuar os orixás.

É sabido que a comunicação está presente em todas as esferas da sociedade, inclusive nos ambientes religiosos. Também é sabido que num processo de comunicação podemos encontrar a comunicação verbal, formada pela oralidade e pela escrita, e a comunicação não verbal, que se envereda pelos meios comunicacionais que não seja a fala. Sendo assim, propusemo-nos a identificar esses dois elementos comunicacionais no ambiente religioso do Santuário Nacional da Umbanda.

Durante a realização da pesquisa de campo, observamos alguns aspectos da comunicação que são relevantes para a identificação dos elementos comunicacionais descritos nessa pesquisa. Percebemos duas situações onde a comunicação verbal está presente no Santuário, que categorizamos como a comunicação escrita observadas nas placas indicativas e cartazes espalhados pelo Santuário, e na oralidade presente nas preces e nos cânticos observados nos ritos dos templos que frequentam o local.

Como já aqui mencionado em capítulo anterior, os pontos cantados são de grande relevância nos cultos da Umbanda, e podemos afirmar que cânticos e preces circundam cerca de $70 \%$ de um culto umbandista. Além de identificarmos as preces e os cânticos como nítida expressão da comunicação verbal, houve também a observância de outro composto comunicacional, que são os elementos paralinguísticos. Os elementos paralinguísticos foram identificados em uma prece cantada a Oxalá:

Raio de luz que ilumina minha vida. Raio de luz que ilumina meu caminhar. A estrela guia brilha lá no céu. Raio de luz, meu pai Oxalá. Oxalá! Olhai seus filhos. Oxalá, tu és a luz que brilha nesse infinito. Nesse astral, sejas bendito (Domínio público).

A prece cantada é um lamento a Oxalá, na condução das almas e no pedido de proteção, ou seja, uma demonstração de pesar na entonação da voz. Logo, podemos relacionála a elementos paralinguísticos, já que:

Constituem os elementos paralinguísticos as qualidades da voz, tais como o registro da voz, a altura, o ritmo, o tempo, aspectos de dicção, a articulação, entonação ou traços suprassegmentais, a ressonância do controle da glote. [...] as vocalizações, que incluem dois aspectos: os caracterizadores vocais, como o sorriso, o suspiro, o bocejo, a rouquidão, e os qualificadores vocais, como a intensidade da voz muito forte ou muito suave, a altura e o arrastar das palavras. (GUIMARÃES, 2009, p. 9$10)$. 
Logo, entendemos que tanto as placas indicativas quanto as preces e pontos cantados pelos adeptos da Umbanda dentro do espaço religioso do Santuário Nacional são considerados elementos comunicacionais verbais, expressados em forma de escrita e de musicalidade.

Quando se trata de comunicação não verbal é importante salientar que em toda a extensão do Santuário é possível observar traços desta. Para tanto, categorizamos o que encontramos em termos de comunicação não verbal dentro do ambiente religioso do Santuário como esculturas, rituais, expressões corporais e elementos da natureza.

$\mathrm{O}$ fato de o Santuário Nacional da Umbanda ser um ambiente rico em símbolos e significados permitiu a observação da presença marcante e numerosa de elementos não verbais da comunicação, o que gerou certa dificuldade em eleger algo em específico para ser analisado. Diante da diversidade de opções e da dificuldade de escolha, optamos por categorizar dois elementos observados: o Vale dos Orixás ${ }^{15}$ e as oferendas aos pés das imagens, juntamente com a análise gestual praticada pelo devoto ou fiel.

Dessa forma, o Vale dos Orixás torna-se um espaço de reflexão e conexão entre o homem e o divino. Ao observar as atitudes dos fiéis aos pés dos monumentos constatou-se esse elo entre a fé, a imagem e o sentido. Ou seja, há uma conexão comunicativa entre ambos, mesmo sem ter a necessidade de se pronunciar uma só palavra.

Também já citado anteriormente, aos pés de cada monumento de orixá há um espaço para oferenda, onde são colocados os amalás e curiadores ${ }^{16}$, e também local próprio para o acendimento de velas votivas. Assim como cada orixá possui características distintas e atuam em forças da natureza diferentes, as oferendas também são produtos identitários de cada santo. No caso observado, Oxalá, representado por Jesus Cristo, é muito reverenciado por sua capacidade de resolução de situações ou problemas complexos e de difícil solução.

Encontramos no Vale dos Orixás as oferendas a Oxóssi, um dos orixás das Sete Linhas da Umbanda, que foram colocadas aos pés da escultura como forma de gratidão e sempre precedidas por uma prece de agradecimento. Outro momento observado foi o ato de uma devota entregando comida a Oxalá, acendendo velas. Nesse momento, a devota realiza uma reza, uma oração que $\log o$ nos mostra o ato comunicacional não verbal entre a adepta e o orixá. Considerando o movimento corporal e o ato de oferecer algo, somos levados à certeza do processo não verbal que está compreendido entre o gesto e seu real sentido.

\footnotetext{
${ }^{15}$ Local específico para culto aos orixás, com esculturas de cada orixá com aproximadamente 10m de altura.

${ }^{16}$ Cf. Dicionário da Umbanda, comidas e bebidas de santo.
} 
Para Guimarães (2009, p. 9), trata-se de uma relação entre o gesto (comunicação não verbal) e seu significado (no caso, a comunicação entre a fiel e o orixá). Assim, durante a pesquisa de campo efetuada no Santuário Nacional da Umbanda para a realização dessa investigação foi possível identificar os elementos das categorias verbais e não verbais da comunicação dentro desse ambiente religioso, ou seja, nos ficou claro que no complexo processo comunicacional, independentemente de ser simbólico, icônico, verbal ou não verbal, a comunicação está presente em larga escala.

\section{CONSIDERAÇÕES FINAIS}

Sabemos que a religião ou o fato de crer em algo é histórico na humanidade e antes de tudo, é uma relação social. Sendo assim, a Umbanda, ao longo do tempo, buscou sua legitimação e é reconhecida como uma religião genuinamente brasileira.

Durante a pesquisa para a produção desse artigo, a relação entre o homem e o divino e foi possível identificar que, não diferente das demais religiões, na Umbanda também está presente os arcabouços da comunicação. Através do acompanhamento de ritos, foi possível identificar que o processo comunicacional está presente em todas as etapas de um culto, seja através de pontos cantados, de preces dirigidas e gestos bem como na significância dos pontos riscados e grafados pelas entidades.

O local é repleto de significados e diante disso, foi imprescindível categorizarmos o que consideramos mais relevante na identificação dos elementos verbais e não verbais da comunicação em dado ambiente. Elegemos aqui como elemento verbal para análise os pontos cantados num templo ou terreiro de Umbanda, buscando relacioná-los com as práticas litúrgicas umbandistas. Para isso, avaliamos as letras de alguns pontos cantados nos terreiros e consideramos que num culto umbandista a presença da música enquanto parte de um processo comunicacional é fundamental, já que os pais ou mães de santo a consideram uma reza cantada.

No que tange aos elementos não verbais, optamos por analisar outro símbolo bastante relevante na Umbanda: os pontos riscados pelas entidades. Por meio de pesquisa de campo, conseguimos traçar a importância dos pontos riscados para a Umbanda, pois, antes de qualquer coisa, é uma marca única e exclusiva de cada entidade, tornando-se assim uma identidade particular. Nessa pesquisa de campo foi possível observar as diversas formas dos pontos riscados, assim como os tipos e suas finalidades. 
Por fim, foi possível chegar ao objetivo principal da dissertação, que busca a identificação dos elementos verbais e não verbais dentro do ambiente religioso do Santuário Nacional da Umbanda. A presente pesquisa é uma pequena contribuição à divulgação do Santuário Nacional da Umbanda, assim como apoio a futuras investigações acerca dos elementos comunicacionais umbandistas que envolvam ritos, simbologias e ícones.

\section{REFERÊNCIAS}

AQUINO, Thiago Antonio Avelar de et al. Atitude religiosa e sentido da vida: um estudo correlacional. Revista Psicologia, ciência e profissão. Brasília, no. 29, v. 2, 2009. Disponível em: < http://www.scielo.br/scielo.php?pid=S1414-

98932009000200003\&script=sci_abstract\&tlng=pt>. Acessado em 9 nov. 2016.

BARROS, Daniel Ítalo Alencar; GOMES, Melina Sousa. Me bote uma dose no copo, acenda uma vela e me faça uma oração: os pontos cantados na umbanda e seus ensinamentos.

Revista Macabéa. São Paulo, v. 3, no. 1, p. 51-72, jun. 2014. Disponível em: < http://periodicos.urca.br/ojs/index.php/MacREN/article/view/742>. Acessado em 2 jan. 2017.

BAUMANN, Igor Pohl. Linguagem simbólica ritual: um estudo de terminologias. Revista Via Teológica. Curitiba, v. 1, p. 110-129, 2010. Disponível em:

<http://www.academia.edu/5171426/Ritual_symbolic_language_a_study_of_terminology >. Acessado em 30 dez. 2016.

DEMÉTRIUS, Lisandro. Umbanda, grande curso completo. São Paulo: Clube de Autores, p. 277-79, 2016.

GALAGARRA, Ana Maria Formoso. A comunicação da experiência religiosa através de símbolos. Anais de Congresso Internacional das Faculdades EST. São Leopoldo (RS): EST, v. 4, p. 1278-1289, 2014. Disponível em:

$<$ http://anais.est.edu.br/index.php/congresso/article/view/412/271>. Acessado em $22 \mathrm{dez}$. 2016.

GUIMARÃES, Rui Dias. Linguagem e comunicação: elementos linguísticos e paralinguísticos, proxémicos e cinésicos. Revista de Letras, série II, no, 1, Vila Real Portugal: Universidade de Trás-os-Montes e Alto Douro-UTAD,. Departamento de Letras, Artes e Comunicação, p. 25-36, dez. 2009.

ORTIZ, Renato. A morte branca do feiticeiro negro: umbanda e sociedade brasileira. São Paulo: Brasiliense, $2^{\text {a }}$. ed., 1999.

PAGLIUSO, Lígia; BAIRRÃO, José Francisco Miguel H. Luz no caminho: corpo, gesto e ato na umbanda. Revista Afro-Ásia. Salvador, no. 42, p. 195-225, 2010. Disponível em: <www.afroasia.ufba.br/pdf/AA_42_LPagliuso_JFMHBairrao.pdf>. Acessado em $30 \mathrm{dez}$. 2016.

PINTO, Altair. Dicionário da umbanda. São Paulo: Eco, 1971. 
PRANDI, Reginaldo. As religiões afro-brasileiras e seus seguidores. Civitas - Revista de Ciências Sociais. Porto Alegre (RS), V. 3, no. 1, p. 16-32, jun./2003. Disponível em: < file://C:/Users/User/Downloads/108-416-2-PB\%20(2).pdf>. Acessado em 3 jun. 2016.

RECTOR, Monica; TRINTA, Aluizio Ramos. Comunicação do corpo. $4^{\text {a }}$. Ed. São Paulo: Ática, 2005.

RIVAS NETO, Francisco. Umbanda: a proto-síntese cósmica. São Paulo: Pensamento, 2002.

SANTOS, Roberto Elísio dos. As teorias da comunicação: da fala à internet. São Paulo: Paulinas, p. 33-36, 2003.

SETTON, Maria da Graça Jacintho. As religiões como agentes de socialização. Cadernos CERU. São Paulo, Série 2, V. 19, no. 2, dez./2008. Disponível em: < http://www.revistas.usp.br/ceru/article/view/11855>. Acessado em 17 jun. 2016.

SOLERA, Osvaldo Ortiz. A magia do ponto riscado na umbanda esotérica. 2014. $95 \mathrm{f}$. Dissertação (Mestrado em Ciências da Religião). Faculdade de Ciências Humanas e Sociais. Pontifícia Universidade Católica de São Paulo, São Paulo, 2014. Disponível em: < https://sapientia.pucsp.br/bitstream/handle/1946/1/Osvaldo\%20Olavo\%20Ortiz\%20Solera.pdf >. Acessado em 3 jan. 2017.

TRINDADE, Diamantino Fernandes. Umbanda brasileira: um século de história. São Paulo: Ícone, 2009.

Doutora com Pós-doutorado em Filosofia pela Universidade de São Paulo, Mestrado e Graduação em Filosofia pela Pontifícia Universidade Católica de São Paulo. Docente do Programa de Pós-Graduação em Comunicação da Universidade Municipal de São Caetano do

Sul - USCS.

Carlos Henrique Oliveira Dias Mestre em Comunicação Social pela Universidade Municipal de São Caetano do Sul (2017). Possui graduação em Licenciatura em Ciências Sociais pela Universidade Nove de Julho

(2011). Possui extensão universitária em Educação de Jovens e Adultos pelo Centro Tecnológico Paula Souza (2014). Atua como professor de Sociologia em escolas de nível médio e técnico.

\section{(C) $\odot \Theta($}

Esta obra está licenciado com uma Licença

Creative Commons Atribuição-NãoComercial-CompartilhaIgual 4.0 Internacional 